\title{
Pengukuran Keimanan: Perspektif Psikologi
}

\author{
Shodiq \\ IAIN Walisongo Semarang \\ Email: shodiq.abdullah@yahoo.co.id
}

\begin{abstract}
Faith material is the basic and essential part of the learning goals in the context of strengthening the students' personalities, especially in teaching religious education. As the purpose of learning, faith must also be evaluated and measured so that it is known to what extent the learning objectives have been achieved. The problem is how to evaluate and measure one's faith? Only Allah can measure and determine the degree of one's faith, don't you? How to measure the faith will be discussed in this paper. This study would be useful for teachers in detecting an increase or decrease of the quality of students' faith in accordance with the indicators that have been determined.
\end{abstract}

Keywords: faith, education of Islamic religion, psychological approach

\begin{abstract}
Abstrak
Pada konteks penguatan kepribadian siswa, materi keimanan dan ketakwaan merupakan bagian pokok dan penting dalam tujuan pembelajaran bagi siswa, khususnya pembelajaran pendidikan agama, tidak terkecuali Pendidikan Agama Islam (PAI). Sebagai tujuan pembelajaran, keimanan juga harus dapat dievaluasi dan diukur sehingga dapat diketahui sejauh mana tujuan pembelajaran tersebut telah tercapai. Persoalannya adalah bagaimana mengevaluasi dan mengukur keimanan seseorang? Tidakkah yang berhak mengukur dan menentukan derajat keimanan seseorang hanyalah Allah, Tuhan Yang Maha Tahu? Bagaimana mengukur keimanan inilah yang hendak dibahas dalam jurnal ini. Sehingga dengan adanya kajian tentang penguatan keimanan secara psikologis, akan bermanfaat bagi guru dalam mendeteksi peningkatan atau penurunan kualitas keimanan anak didik sesuai indikator keimanan yang sudah ditentukan.
\end{abstract}

Kata kunci: keimanan, PAI, dan pendekatan psikologis. 


\section{A. Pendahuluan}

Pendidikan nasional bertujuan untuk "mengembangkan potensi peserta didik agar menjadi manusia yang beriman dan bertakwa kepada Tuhan Yang Maha Esa, berakhlak mulia, sehat, berilmu, cakap, kreatif, mandiri, dan menjadi warga negara yang demokratis serta bertanggung jawab" (UU RI Nomor 20 Tahun 2003, Pasal 3). Untuk itu kurikulum pendidikan pada jenjang pendidikan dasar dan menengah dikembangkan menjadi lima kelompok mata pelajaran, yaitu: 1) kelompok mata pelajaran agama dan akhlak mulia, 2) kelompok mata pelajaran kewarganegaraan dan kepribadian, 3) kelompok mata pelajaran ilmu pengetahuan dan teknologi, 4) kelompok mata pelajaran estetika, 5) kelompok mata pelajaran jasmani, olah raga dan kesehatan. (PP Nomor 19 Tahun 2005 tentang Standar Nasional Pendidikan, Pasal 6 Ayat 1).

Lebih lanjut disebutkan bahwa kelompok mata pelajaran agama dan akhlak mulia dimaksudkan untuk membentuk peserta didik menjadi manusia yang beriman dan bertakwa kepada Tuhan Yang Maha Esa serta berakhlak mulia. Akhlak mulia mencakup etika, budi pekerti atau moral sebagai perwujudan dari pendidikan agama. Dengan demikian dapat dikatakan bahwa mencetak dan mewujudkan manusia Indonesia yang beriman, bertakwa, dan berakhlak mulia merupakan tanggung jawab utama mata pelajaran pendidikan agama. Dalam konteks inilah dapat dipahami dan diterima kritik, bahwa terjadinya kemerosotan akhlak dan semakin dangkalnya keimanan di kalangan umat beragama di Indonesia merupakan indikasi "kegagalan" pelaksanaan pendidikan agama.

\section{B. Teori Iman dalam Teologi Islam}

Secara etimologis, kata "iman" berasal dari Bahasa Arab, dan merupakan bentuk masdar dari akar kata: 1) àmana; yang berarti "good faith, sincerity" (percaya), 2) amāna; yang berarti "fidelity, loyality" (ketaatan, kesetiaan), 3) amān; yang berarti "protection granted" (diberikan perlindungan, aman), dan 4) àmana; yang berarti "to believe, to give one's faith" (percaya, mempercayai) dan "to protect, to place in safety" (melindungi, menempatkan [sesuatu] pada tempat yang aman). Dari beberapa arti kata "iman" tersebut dapat ditegaskan bahwa, secara etimologis "iman" berarti "kepercayaan atau pembenaran", yakni sikap membenarkan sesuatu, atau menganggap dan mempercayai sesuatu yang benar. 
Jadi, "iman" adalah "faith, yakni kepercayaan, dan orang yang beriman disebut "mukmin". 1

Al-Qur'an menyebut kata "imān" dalam berbagai bentuk kata jadian tidak kurang dari $550 \mathrm{kali}$, seperti: àman̄, yu'minu, yu'minūn, mu'mīn, dan mu'minūn. Bahkan menurut Ali Audah, bahwa kata "imān" dalam berbagai bentuknya ditemukan sebanyak 718 kali dalam al-Quran. ${ }^{2}$ Kadang-kadang penyebutan tersebut digunakan untuk menunjuk "ciri perilaku" atau sifat orang beriman, dan kadang-kadang menunjuk kepada "obyek" yang harus diimani. Penyebutan kata "imān" dalam al-Quran yang berulang-ulang ini dapat dipahami bahwa "iman" merupakan sesuatu yang sangat penting dalam kehidupan manusia, dan sekaligus merupakan kunci pokok dalam membentuk keislaman dan kepribadian seseorang.

Persoalan yang kemudian muncul dan menjadi wacana serius dalam Teologi Islam adalah; apakah sikap membenarkan dan mempercayai cukup dilakukan di dalam hati (tassdiq bi al-qalb)? Ataukah keimanan juga harus ditunjukkan dengan perbuatan lahir dalam bentuk pernyataan lisan (iqrār bi al-lisān), atau bahkan juga harus ditunjukkan dengan perbuatan anggota badan yang lain; dengan mengerjakan 'amal sebagaimana diajarkan dalam doktrin dan ajaran yang diimani ('amal bi al-arkan)? Pembahasan dan diskusi di antara para teolog muslim mengenai hal ini melahirkan beberapa pandangan atau konsepsi, atau dapat disebut sebagai teori, tentang iman sebagaimana dijelaskan pada uraian berikut.

\section{Teori Ma'rifah}

Teori atau pandangan ini secara umum dikemukakan oleh para tokoh Murji'ah, terutama golongan Murji'ah ekstrim, dan di antara tokohnya yang terkenal adalah Jahm ibn Șafwan. Menurut pandangan kelompok ini, bahwa iman adalah pengetahuan (ma'rifah) terhadap Tuhan dan utusan-Nya serta semua yang datang dari Tuhan. Semuanya yang berada di luar bentuk "pengetahuan" ini bukanlah iman. Iman tidak ada hubungannya dengan perbuatan lahir, baik pernyataan secara lisan ataupun perbuatan anggota badan yang lain. Komponen atau faktor

${ }^{1}$ Lewis, Bernard et al, The Encyclopaedia of Islam. Volume III, New Edition, (Leiden: E.J. Brill, 1971), hlm. 1173.

${ }^{2}$ Ali Audah, Konkordansi Quran: Panduan Kata dalam Mencari Ayat Qur'an, (Bogor: Pustaka Litera Antar Nusa, 2003), hlm. 77-81. 
iman hanyalah satu, yakni pengetahuan. Dengan demikian, struktur esensial iman adalah ma'rifah.

Teori ma'rifah tampaknya sangat lemah, sehingga banyak mendapatkan kritik. Abū Manșur al-Maturidi, salah satu tokoh pemikir teologi Islam yang diidentifikasi sebagai salah satu tokoh penting dari golongan Ahl al-Sunnah wa-al-Jamā'ah, menyatakan bahwa; iman harus dipahami sebagai pembenaran (tașdiq), dan bukan pengetahuan (ma'rifah). Bahwa kata iman sendiri secara etimologis berarti "pembenaran", dan ini juga harus menjadi makna teologis dasar dari iman. ${ }^{3}$

2. Teori Amaliyah

Menurut kelompok Mu'tazilah, bahwa iman bukanlah sekedar ma'rifah (mengetahui), dan bukan pula sekedar taṣdiq (membenarkan, meyakini), tetapi amal yang timbul sebagai akibat dari mengetahui Tuhan. Iman tidak hanya mempunyai arti pasif, tetapi mesti mempunyai arti aktif. Iman adalah pelaksanaan perintah perintah Tuhan. Menurut Abu Hużail, salah seorang tokoh Mu'tazilah, bahwa yang dimaksud dengan perintah-perintah Tuhan adalah semua perintah baik yang wajib maupun yang sunnah. Sedangkan menurut al-Jubba'i, tokoh Mu'tazilah yang lain, bahwa yang dimaksud perintah-perintah Tuhan adalah perintah-perintah Tuhan yang bersifat wajib. ${ }^{4}$

Dengan demikian dapat ditegaskan bahwa hal yang pokok dari imān adalah amal, dan bukan ma'rifah atau tașdiq. Sehingga siapa pun yang telah membenarkan bahwa tiada Tuhan selain Allah dan membenarkan Muhammad sebagai utusanNya, apabila ia tidak melaksanakan perintah-perintah Allah dan meninggalkan larangan-larangan-Nya, maka ia tidaklah beriman.

\section{Teori Tașdiq}

Tokoh pertama dan utama dari kelompok Asy'ariyah adalah Abū Hasan al-Asy'ariy. Dalam Kitab al-Luma, seperti dikutip dan dijelaskan Izutsu, al-Asy'ariy mendefinisikan imān sebagai “tașdiq kepada Tuhan”. Di sini al-Asy'ary menegaskan

${ }^{3}$ Toshihiko Izutsu, Konsep Kepercayaan dalam Teologi Islam: Analisis Semantik Iman dan Islam, terj. Agus Fahri Husein dkk. (Yogyakarta: Tiara Wacana, 1994), hlm. 153.

${ }^{4}$ Nasution, Harun, Teologi Islam: Aliran-aliran, Sejarah Analisa Perbandingan, (Jakarta: UI Press, 2002), hlm. 147. 
bahwa secara linguistik ini merupakan satu-satunya interpretasi yang masuk akal untuk kata iman. Secara etimologis, kata "imān" berarti tașdiq (pembenaran). Sementara dalam Kitab alIbanah al-Asy'ariy menyatakan bahwa: "Kami tegaskan bahwa Isläm merupakan suatu konsep yang lebih luas dari ïmān, tidak semua Islam adalah iman (sementara semua iman adalah Islam), dan bahwa iman adalah "mengatakan" dan "melakukan" (al-ïmān qawl wa 'amal), dan dapat naik serta turun". Menurut Izutsu, bahwa tidak disebutnya tașdiq di sini tidak menunjukkan bahwa al-Asy'ariy tidak memandang tașdiq sebagai unsur yang penting, sebaliknya al-Asy'ary memandang tașdiq sedemikian penting dan essensial sehingga tidak perlu disebutkan secara eksplisit. ${ }^{5}$

Berkaitan dengan penjelasan al-Asy'ariy tentang iman yang berbeda dalam dua karyanya tersebut, al-Syahrastani dalam Al-Milal wa al-Nihal, memberikan penjelasan bahwa, "Asy'ariy berpendapat: iman secara essensial adalah taşdiq dengan hati, sementara "mengatakan" dengan lisan dan "melakukan" berbagai kewajiban yang utama sekadar merupakan cabang-cabangnya. Oleh karena itu, orang yang percaya sesungguhnya adalah mereka yang memberikan pembenaran terhadap ke-Esa-an Tuhan dengan hatinya, yaitu mereka yang mengakui kebenaran-Nya serta menerima utusan-Nya. Iman dari orang semacam itu merupakan kepercayaan yang sesungguhnya".

Di sini al-Syahrastaniy menegaskan bahwa, menurut Asy'ariy, tașdiq (dengan hati) merupakan satu-satunya hal yang penting, sementara qaul dan 'amal sekadar mempunyai makna penting kedua, walaupun keduanya tidak dikeluarkan dari definisi iman.

Pandangan al-Asy'ariy tersebut diikuti dan dijelaskan lebih lanjut oleh para ulama Asy'ariyah, salah satunya adalah alGhazali. Muhammad ibn Muhammad al-Ghazali, seperti ditulis dalam "Kitab Qawā'id al-Aqā'id" yang merupakan karya induk al-Ghazāliy di bidang akidah dan kini menjadi salah satu bab dari Kitab Ihyā Ulüm al-Dīn, menjelaskan bahwa iman adalah sikap pembenaran (tașdiq) di dalam hati, sedangkan pernyataan atau pengakuan dengan lidah (iqrār) dan perbuatan

${ }^{5}$ Izutsu, The Concept of Belief ..., hlm. 160. 
dengan anggota badan (amal) merupakan bagian yang menyempurnakan iman.

Zurkāni Jahja menjelaskan bahwa, al-Gazāliy membandingkan status tașdiq bagi iman seperti status kepala dan badan bagi tubuh manusia. Tanpa badan dan kepala, manusia tidak bisa hidup. Jadi, tanpa taṣdiq iman tidak ada. Iqrär dan amal statusnya hanya sebagaimana status kaki dan tangan bagi manusia. Manusia tanpa kaki dan tangan masih bisa hidup, tetapi tidak sempurna. Dengan demikian, bagian esensial dari iman adalah "tașdiq" di dalam hati. Dengan "tașdiq" berarti iman sudah ada, dan dengan amal iman bisa bertambah sempurna dan bisa berkurang, tetapi tidak sampai menghapuskan eksistensinya. ${ }^{6}$

4. Teori Amal al-Qalb

Menurut Ibnu Taimiyah, secara semantik konsep iman tidak cukup untuk didefinisikan dengan tașdiq, karena iman tidak sekadar tașdiq. Tașdiq bukan sinonim dari iman. Kata tașdiq berarti "membenarkan", yakni menilai bahwa suatu informasi atau laporan tersebut benar. Lawan katanya adalah takżib, yakni menilai bahwa informasi atau laporan tersebut salah.

Kata "iman" merupakan derivasi dari kata "amn", yang mempunyai makna "ketenteraman", "merasa aman dan terlindung", "pikiran merasa damai". Dengan demikian, kata ìmān atau konsep iman tidak saja mengandung unsur tașdiq (pembenaran), akan tetapi lebih dari itu adalah mencakup makna "menetapkan keyakinan" (i’timān) dan "kepercayaan" (āmanah).

Lebih lanjut Ibnu Taimiyah menjelaskan, bahwa tașdiq hanya cukup menetapkan seorang manusia menjadi muslim, akan tetapi tidak dapat menjaminnya untuk menjadi mu'min (orang yang beriman), kecuali disertai dengan perbuatan baik. Jadi, perbuatan atau amal merupakan bagian tak terpisahkan dari ìmān, atau merupakan struktur esensial dari iman.

Apakah yang dimaksud amal sebagai komponen struktur esensial imān oleh Ibnu Taimiyah? Menurutnya, bahwa yang dimaksud amal sebagai bagian tidak terpisahkan dari konsep

\footnotetext{
${ }^{6}$ Zurkani Jahja, Teologi al-Ghazali: Pendekatan Metodologi, (Yogyakar-
} ta: Pustaka Pelajar, 1996), hlm. 104. 
iman adalah ' amal al-qalb (perbuatan hati) yang berfungsi sebagai semacam rantai yang menghubungkan antara tașdiq yang sifatnya murni di dalam dan statik dengan amal jasmaniah yang sifatnya murni di luar dan aktif. Jelas terdapat hubungan iman dengan amal, bahkan amal dimulai pada tingkat yang lebih dalam dibandingkan dari anggota tubuh yang eksternal, yaitu hati ( $q a l b)$ itu sendiri yang mempunyai perbuatannya sendiri. Cinta kepada Tuhan dan utusan-Nya, sebagai contoh, merupakan "tindakan" psikologi, dan berbagai macam tindakan psikologi merupakan amal dalam pengertian kata yang nyata, sebagaimana tindakan tubuh yang bersifat eksternal itu merupakan amal.

Dalam Kitāb al-Imān Ibnu Taimiyyah memberikan penjelasan tentang konsep 'amal al-qalb dengan ilustrasi sebagai berikut: Pelaku perbuatan zina, ketika dia melakukan perbuatan zina, hanya melakukan hal itu karena dia mencintai perbuatan itu di dalam hatinya. Dia tidak akan melakukan perbuatan zina itu apabila di dalam hatinya terdapat ketakutan nyata (khasyyah) terhadap Tuhan yang cukup kuat untuk menekan keinginannya itu, atau terdapat cinta (mahabbah) kepada Tuhan yang begitu besar sehingga dapat mengatasi keinginannya itu. Oleh karena itu, orang yang benar-benar mencintai dan yakin terhadap Tuhan maka dia tidak akan pernah melakukan zina. Seseorang yang melakukan zina karena dia tidak mempunyai sifat cinta (mahabbah) dan atau takut (khasyyah) kepada Allah. Dan ini merupakan jenis iman yang dapat hilang dari hati manusia, walaupun dia tidak akan pernah kehilangan tașdiq itu sendiri. Itulah sebabnya, orang semacam ini dikatakan seorang muslim, dan bukan seorang mukmin.

Singkatnya, Ibnu Taimiyah menegaskan bahwa barang siapa di dalam hatinya tidak terdapat semua kondisi yang diperlukan dalam iman, walaupun dia mempunyai tașdiq, maka dia termasuk orang yang dinyatakan oleh Nabi saw., sebagai orang yang di dalam hatinya tidak terdapat imān. Tașdiq hanya merupakan suatu bagian dari imān. Masih harus ada tambahan lain pada tașdiq, misalnya kecintaan (mahabbah) kepada Tuhan, serta rasa takut (khasyyah) kepada Tuhan. Tașdiq yang mengabaikan hal-hal ini bukan iman sama sekali. ${ }^{7}$

${ }^{7}$ Izutsu, The Concept of Belief ..., hlm. 195. 


\section{Mengukur Keimanan dalam Perspektif Psikologi}

1. Konstruk Iman

Sebagaimana diuraikan pada bagian sebelumnya bahwa tidak terdapat kesepakatan di antara ahli teologi Islam tentang definisi dan struktur esensial iman. Hal ini dapat dipahami karena al-Quran dan Hadis sebagai sumber utama Islam tidak memberikan rumusan yang baku tentang definisi ataupun struktur esensial iman. Walapun banyak ayat al-Quran dan Hadis Nabi saw, yang menyebutkan tentang iman atau keimanan, namun penyebutan lebih berkaitan dengan obyek iman dan atau ciri-ciri perilaku orang yang beriman.

Merujuk pada beberapa teori iman dalam Teologi Islam, sebagaimana dijelaskan di atas, dapat dirumuskan bahwa konstruksi keimanan mencakup dua dimensi pokok, yaitu dimensi batin dan dimensi lahir. Dimensi batiniah (internal act) adalah kondisi dan perbuatan batin atau kejiwaan yang melibatkan ranah kognisi, afeksi, dan konasi secara bersama-sama. Dimensi ini terdiri dari: a) dimensi keyakinan, yakni mempercayai atau meyakini dengan sepenuh hati doktrin dan ajaran agama Islam (Dīn al-Isläm) yang meliputi keyakinan kepada: Allah, Malaikat, Rasul, Kitab Suci, Qaḍā' dan Qadar Allah, serta Hari Akhir. b) dimensi sikap, yaitu sikap batin dalam menerima keadaan dan sekaligus adanya keinginan yang kuat di dalam hati untuk menjalani kehidupan sesuai dengan perintah dan aturan Allah swt.

Dimensi lahir (external act) adalah perilaku atau tindakan anggota badan yang bersifat empirik, baik berupa perkataan lisan maupun perbuatan anggota badan lainnya. Perilaku lahiriah (external act) ini merupakan manifestasi dari kondisi dan perbuatan batin (internal act).

Konstruk teoritik keimanan tersebut dapat digambarkan sebagai berikut:

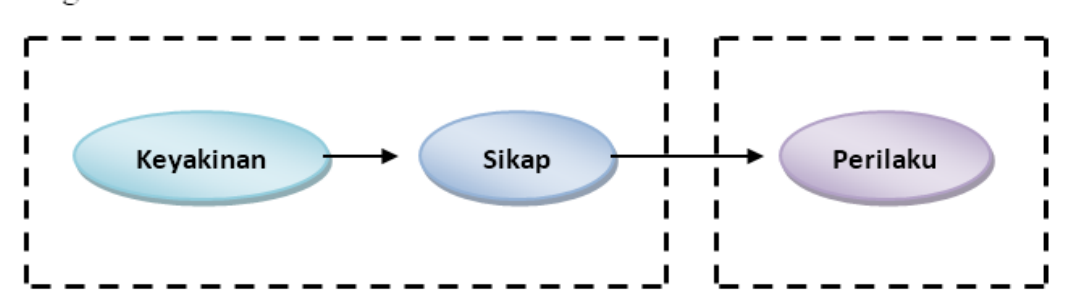


Dalam perspektif psikologis, dimensi batin dari iman merupakan aspek iman yang berkaitan dengan keadaan dan perbuatan kejiwaan seseorang baik pada ranah kognisi (pikiran), afeksi (perasaan atau emosi), dan konasi (kehendak). Dimensi ini berkaitan dengan keyakinan dan sikap batin seseorang. Sedangkan dimensi lahir dari iman berkaitan dengan tindakan dan perbuatan lahir yang didorong dan digerakkan oleh keyakinan dan sikap batin, baik kegiatan yang berkaitan dengan praktek ritual agama (ibadah mahdah) maupun kegiatan sosial kemasyarakatan (ibadah gairu mahdiah).

Pandangan dan konstruksi teoritik iman seperti tersebut di atas selaras dengan pandangan Zakiah Daradjat yang menyatakan bahwa: Keimanan adalah suatu proses kejiwaan yang tercakup di dalamnya semua fungsi jiwa, perasaan dan pikiran sama-sama meyakinkannya. ${ }^{8}$ Keimanan adalah proses kejiwaan yang melibatkan fungsi kognisi dan afeksi secara bersama. Keimanan yang sesungguhnya harus ada realisasinya dalam segala sikap dan tindakan. Orang yang benar-benar beriman (mu'min) akan merasa rị̣a dan ikhlas, tidak merasa kesepian, resah dan cemas, hatinya tenteram dan bahagia.

Konstruksi teoritik iman seperti tersebut di atas juga selaras dengan pandangan James W. Ellor yang menyatakan bahwa, iman merupakan spiritual domains yang terdiri dari tiga ranah, yaitu: 1) cognitive;meliputi pengetahuan dan kepercayaan, 2) affective;meliputi kejiwaan seseorang, sikap terhadap dirinya dan di luar diri sendiri, 3) behavioural; termasuk di dalamnya kegiatan yang berhubungan dengan praktik dan ritual agama.

Selanjutnya, menurut Teori Fakulti bahwa tingkah laku manusia, termasuk di dalamnya perbuatan manusia yang bersifat keagamaan, tidak bersumber pada suatu faktor yang tunggal tetapi bersumber dari beberapa unsur, yang dianggap penting adalah: fungsi cipta (reason), rasa (emotion), dan karsa (will).

Cipta (reason) merupakan fungsi intelektual jiwa manusia. Melalui daya cipta yang dimilikinya seseorang dapat menilai, menentukan, dan selanjutnya memutuskan suatu tindakan terhadap stimulan tertentu. Dalam kehidupan keagamaan, daya

${ }^{8}$ Zakiah Daradjat, Ilmu Jiwa Agama, (Jakarta: Bulan Bintang, 1990), hlm. 14-16. 
cipta (reason) berperan untuk menentukan benar atau tidaknya ajaran suatu agama berdasarkan pertimbangan intelek seseorang. Rasa (emotion) merupakan suatu daya dalam jiwa manusia yang banyak berperan dalam membentuk motivasi dalam corak tingkah laku seseorang. Dalam kehidupan keagamaan, daya rasa (emotion) berperan menimbulkan sikap batin yang seimbang dan positif dalam menghayati kebenaran ajaran agama.

Karsa (will) merupakan fungsi eksekutif dalam jiwa manusia yang berfungsi mendorong timbulnya pelaksanaan doktrin dan ajaran agama berdasarkan fungsi kejiwaan. Dalam kehidupan keagamaan, daya karsa (will) berperan mendorong, menggerakkan, dan menimbulkan amalan-amalan keagamaan yang benar dan logis. Apabila tingkah laku atau amalan-amalan keagamaan yang terwujud dalam kehidupan keseharian seseorang sesuai dengan ajaran agama dan selalu mengimbangi tingkah lakunya, maka berarti fungsi will-nya kuat. Apabila seseorang berbuat sesuatu yang bertentangan dengan kehendaknya (will-nya), maka berarti fungsi will-nya lemah.

Mungkin saja pengalaman agama seseorang bersifat intelek atau pun emosi, namun jika tanpa adanya karsa (will), agama tersebut belum tentu terwujud sesuai dengan kehendak reason atau emosi. Karena itu, diperlukan adanya suatu tenaga pendorong agar ajaran agama menjadi suatu tindak keagamaan. Suatu kepercayaan yang dianut seseorang tidak akan berarti sama sekali apabila dalam keyakinan tersebut will tidak befungsi secara wajar.

2. Pengukuran Keimanan

Sebagaimana diuraikan pada bagian terdahulu bahwa persoalan imān atau keimanan merupakan persoalan hati dan atau keadaan jiwa seseorang. Keadaan hati dan jiwa inilah yang akan menggerakkan dan mengarahkan perbuatan seseorang. Dari sini dapat dipahami bahwa pembahasan tentang iman atau keimanan dapat dikaji dari perspektif ilmu jiwa atau psikologi.

Atribut psikologis yang biasa dipersoalkan dalam psikologi tidak mempunyai eksistensi riil. Eksistensi dan struktur atribut psikologis dibangun secara teoritik atau disebut rekaan teoritis (theoretical construct). Dalam kaitan ini, konstruksi teoritik keimanan, sebagaimana telah dijelaskan pada bagian terdahulu, mencakup tiga dimensi atau aspek, yaitu: keyakinan (tașdiq bi 
al-qalb), sikap dan perasaan ( 'amal al-qalb), dan perilaku atau perbuatan-perbuatan anggota badan ('amal al-jawāriḥ).

Sebagai konstruksi psikologi, iman atau keimanan bersifat hipotesis yang tidak dapat diobservasi dan diukur secara langsung. Keberadaannya hanya dapat diinfer dari konsekuensinya. Iman atau keimanan menjadi variabel laten yang tidak bisa diamati dan diukur secara langsung, tetapi dapat diamati dan diukur dari gejala atau manifestasi yang ditampakannya (variabel amatan). Sumadi Suryabrata menjelaskan bahwa, karena kehidupan psikologi tidak dapat diamati secara langsung (unobservable), maka yang dapat dikaji dan diukur adalah fungsi dan ciri-ciri psikologi yang ditampilkannya.

Lebih lanjut perlu ditegaskan dan dipahami bahwa, oleh karena kualitas dan kuantitas iman atau keimanan hanya dapat diinfer dari variabel lain yang dapat diamati dan diukur (variabel amatan atau indikator), maka validitas skala keimanan sangat tergantung pada seberapa dekat variabel lain tersebut (variabel amatan atau indikator) dapat mencerminkan karakteristik iman atau keimanan yang sedang diukur.

Secara garis besar, atribut psikologi dapat digolongkan menjadi dua kelompok, yaitu: 1) atribut-atribut kognitif, dan 2) atribut-atribut nonkognitif. Mengikuti pemilahan ini, maka iman atau keimanan termasuk dalam kelompok atribut nonkognitif. Penegasan ini sangat penting kaitannya dengan teknik pengukuran dan interpretasi hasil pengukuran, karena secara mendasar berbeda antara pengukuran atribut kognitif dengan pengukuran atribut nonkognitif. Menurut Howard B. Lyman, pengukuran ranah kognitif dan psikomotor mengukur kinerja maksimum, sedangkan pengukuran ranah afektif mengukur kinerja tipikal.

Pada pengukuran kinerja maksimum, jawaban benar sama untuk semua peserta, dan mereka diasumsikan memiliki motivasi yang sama tingginya pada saat pengukuran dilakukan Lyman. Perbedaan respons atau jawaban antar peserta tergantung pada kemampuannya, yang dipengaruhi oleh kemampuan bawaan atau perolehan. Dalam merespon butir instrumen atau pertanyaan, peserta diharapkan berusaha secara maksimal untuk menjawab dengan benar. Konsekuensinya, jawaban mereka mungkin benar atau salah, tergantung kesesuaiannya dengan yang diharapkan. 
Sementara pada pengukuran kinerja tipikal, jawaban yang benar atau ideal untuk masing-masing butir atau item pertanyaan adalah jawaban yang benar bagi peserta tertentu, meskipun secara pendidikan dan sosial (termasuk agama) mungkin bukan merupakan jawaban yang diharapkan. Dalam merespon butir instrumen atau pertanyaan, peserta tidak diharapkan berupaya melakukan yang terbaik, tetapi diharapkan menjawab secara jujur.

Konsekuensinya, walaupun terdapat perbedaan jawaban antar peserta, tetapi tidak ada jawaban yang dianggap salah, selama sesuai dengan kenyataan yang menunjukkan kejujuran mereka. Atau dalam bahasa Sumadi Suryabrata, bahwa "pengukuran atribut nonkognitif diperlukan respons jenis ekspresi (expression of sentiment), yaitu jenis respons yang tak dapat dinyatakan benar atau salah, atau sering kali dikatakan semua respons benar menurut alasannya masing-masing." Perbedaan jawaban atau respons hanyalah menunjukkan adanya perbedaan tingkatan dalam skala kontinum afektif. Para ahli pengukuran telah mengembangkan berbagai teknik untuk mengungkap status individu dalam kontinum afektif. Di antara teknik yang ditawarkan dan telah digunakan dalam bidang pendidikan adalah: observasi, unobtrusif, interview, kuesioner, dan skala.

\section{Penutup}

Persoalan keimanan sebenarnya lebih merupakan persoalan keadaan kejiwaan seseorang, dan oleh karena itu, untuk memahaminya juga diperlukan pendekatan dan perspektif psikologi. Lebih dari itu, oleh karena keimanan juga bisa bertambah dan berkurang, maka keimanan juga dapat diukur (measureable). Ada beberapa teknik pengukuran yang dapat digunakan untuk mengukur keimanan; skala, angket, observasi, dan lain-lain. Walaupun demikian harus tetap disadari betul bahwa hasil pengukuran beberapa teknik tersebut tidak dapat mencapai validitas dan atau reliabilitas yang maksimal.

\section{Kepustakaan}

Ahyadi, Abdul Aziz, Psikologi Agama Kepribadian Muslim Pancasila, (Bandung: Sinar Baru, 1999). 
Afandi, Abdullah Khozin, Ilmu dan Iman dalam Wawasan alQur'an., (Yogyakarta: Disertasi IAIN Sunan Kalijaga, 1997). tidak diterbitkan.

Warson Munawwir, Ahmad, Al-Munawwir: Kamus Arab-Indonesia. (Yogyakarta: al-Munawwir, 1984).

al-Ashfahany, al-Ragi>b, Al-Mufradāt fí Garīb al-Qur'ān, (Mesir: Muștafa al-Babi al-Halabi wa Awlādih, 1961).

al-Bukhāriy, Abi Abdillah Muh\}ammad bin Isma>'i>1, Sahịh alBukhari, juz I, (Mesir: Dar Ihya al-Kutub, 1961).

al-Gazāliy, Abū Ḥamid Muhammad bin Muhammad, Ihȳa Ulūm alDin, (Beirut: Da>r al-Ma'rifah, t.t.).

Ali Audah, Konkordansi Qurān: Panduan Kata dalam Mencari Ayat Qüran, (Bogor: Pustaka Litera Antar Nusa, 2003).

Anastasi, Anne \& Susana Urbina, Tes Psikologi, terj. Robertus Hariono S. Imam, (Jakarta: Indeks, 2007).

Cronbach, J. S., Essential of Psychological Testing, (New York: Harper and Raw Publisher, 1970).

Ebel, Robert L., Essential of Educational Measurement, (London: Prentice Hall, 1979).

Edwards, A.L., Technique of Attitude Scala Constraction, (New York: Appleton Century Crofts, 1957).

Fishbein, Martin \& Ajzen Icek, Belief, Attitude, Intention and Behavior: an Introduction to Theory and Research, (London: Addison, Wesley Publishing, 1975).

Fishbein, Martin \& Ajzen Icek, Understanding Attitude and Predicting Social Behavior, (New Jersey: Prentice Hall, 1980).

Guilford, L. J., Psychometric Methods, (New York: Mc. Graw-Hill, 1981).

Hadjar, Ibnu, Dasar-dasar Metodologi Penelitian Kuantitatif dalam Pendidikan, (Jakarta: RajaGrafindo Persada, 1999).

Hasan, Riaz, Faitlines: Muslim Conception of Islām and Society. Terj. Jajang Jahroni dkk. Keragaman Iman: Studi Komparatif Masyarakat Muslim, (Jakarta: Rajawali Grafindo Persada, 2006).

Ibn Taymiyah, Kitab al-Imān, (Damascus: Da>r al-Fikr, 1961). 
Izutsu, Toshihiko, Konsep Kepercayaan dalam Teologi Islam: Analisis Semantik Iman dan Islam, terj. Agus Fahri Husein dkk. (Yogyakarta: Tiara Wacana, 1994).

Izutsu, Toshihiko, Konsep-konsep Etika Religius dalam al-Qurān Ethico Religious Concepts in the Qurān, terj. Agus Fahri Husain dkk,. (Yogyakarta: Tiara Wacana, 2003).

Jahja, Zurkani, Teologi al-Ghazali: Pendekatan Metodologi, (Yogyakarta: Pustaka Pelajar, 1960.

John Sealey, Religious Education: Philosophical Perspectives, (London: George Allen \& Unwin, 1984).

Krathwohl, David R., Benjamin Bloom \& Bertran B. Masia, Taxonomy of Educational Objective: Affective Domain, (London: Longman Group, 1973).

Lewis, Bernard et al., The Encyclopaedia of Islam, vol. III, New Edition, (Leiden: E.J. Brill, 1971).

Mas'ud, Abdurrahman, Menggagas Format Pendidikan Non Dikotomik: Humanisme Religius sebagai Paradigma Pendidikan Islam, (Yogyakarta: Gama Media, 2002).

Masri, Asma Jana \& Priester, Paul E., "The Development and Validation of Qur'an-based Instrument to Assess Islamic Religiosity: the Religiosity of Islam Scale", Journal of Muslim Mental Health, (2007).

Nasution, Harun, Teologi Islam: Aliran-aliran, Sejarah Analisa Perbandingan, (Jakarta: UI Press, 2002).

Najati, M. Utsman, Al-Qurān dan Ilmu Jiwa, terj. Ahmad Rofi Usmani, (Bandung: Pustaka, 1985).

Paloutzian, Raymond F. \& Crystal L. Park (ed.), Handbook of the Psychology of Religion and Spirituality, (New York: The Guilford Press, 2005).

Sabiq, Sayyid, Akidah Islam, terj. Ahmad Rofi Usmani (Bandung: Diponegoro, 1986).

Subandi, Psikologi Zikir: Studi Fenomenologi Pengalaman Transformasi Religius, (Yogyakarta: Pustaka Pelajar, 2006).

Undang-undang Nomor 20 Tahun 2003 tentang Sistem Pendidikan Nasional.

Zakiah Daradjat, Ilmu Jiwa Agama, (Jakarta: Bulan Bintang, 1990). Zamroni, “ Penilaian Hasil Pendidikan Agama Islam Ranah Afektif”, Jurnal Penelitian Agama, (vol. 2/1993). 
